\title{
An Assessment of Crop Farmer Households' Perceptions of Climate Change and Coping Strategies in Kano State, Nigeria
}

\author{
H. A. Yusuf \\ Department of Agricultural Economics and Rural Sociology, Faculty of Agriculture, Ahmadu Bello University, Zaria. \\ [turai74@yahoo.co.uk; hagiwa69@gmail.com; P: +2347068300505]
}

\begin{abstract}
The study assessed crop farmer households' perceptions of climate change and coping strategies in Kano State of Nigeria. Data for this study were obtained by the use of structured questionnaire and household head was used as the sampling unit. A total sample size of 407 crop farmer households were selected through simple random sampling and it represent $20 \%$ of the sample frame of 2036 . Descriptive statistics such as percentage and mean scores were used to analyse the data collected for the study. Perception of farm household was judged by the mean scores derived from the 5-point Likert items. The study revealed that decrease in crop production (mean score $M=5$ ) was the major perceived climate change effect on their crop production. This was followed by decrease in food availability $(M=4.25)$, decrease soil fertility $(M=3.86)$ and increase pest and disease infestation $(M=3.79)$. The average mean score of the farmer's perception of climate change on crop production was 3.93. This implies that the respondents in the study area agreed that climate change lead to decrease in crop production. The major coping strategy adopted by farmers in the study area was changing crop variety which was indicated by about $80 \%$ of the respondents. Other coping strategies include crop rotation (about 41\%), mixed cropping and shifting cultivation constituting about $34 \%$ respectively. Based on these findings, it is recommended that crop farmers in the study area should be encouraged to use farm level adaptation measures. This can be achieved through developing appropriate farm-level climate adaptation technologies by research institutes and disseminating them to farmers at the appropriate time. Since most respondents used different varieties of crops to cope with climate change effects in the study area, agricultural organizations and research institute should put more effort in developing new varieties of crop that will suit the climatic conditions of the farmers and farmers should have direct link with the research institutes or seed companies in order to have access to the new seed varieties.
\end{abstract}

Keywords: Perception, coping strategies, crop farmer, household, climate change.

\section{INTRODUCTION}

The intergovernmental panel on climate change (IPCC) defined climate change as statistically significant variations that persist for an extended period, typically decades or longer. It includes shifts in the frequency and magnitude of sporadic weather events as well as the rise in global mean surface temperature. Changes in climate are attributed directly or indirectly to human activities and alter the composition of the global atmosphere (IPCC, 2007). Climate change can also be defined as any change in climate over time, whether due to natural variability or as a result of human activity and is widely recognized as the most serious environmental threat facing our planet today (Ozor, 2009). Perception is the process of attaining awareness or understanding of sensory information. According to Ofuoku (2011), man views his environment from the way he feels about it in his interaction with it. Depending on how he perceives and interprets the environment, he reacts to secure his comfort and future.

Farmers' perception of their environment is a factor of climate change. Hence, adaption to climate change requires that farmers must first notice that the climate has change and then identify useful adaptation and implement them (Maddison, 2006). Building up resilience to 
increasing climate variability is the most significant climate challenge facing all countries including Nigeria. Countries need to factor climate risks and climate change adaptation into their developing planning, and consider the range of interventions that increase their resilience to climate change (Eboh, 2009).

In Nigeria, non-governmental organizations like Nigerian Environmental Study/Action Team (NEST) and Greenwatch Initiative working in partnership with Building Nigeria Response to Climate Change (BNRCC) project have taken adaptation measures such as livelihood diversification strategies, improved access to water, ecosystem rehabilitation and other adaptation measures to reduce the negative effect of climate change on the livelihood of vulnerable people (BNRCC, 2009). The major challenge here is that the adaptation measures mentioned cannot meet large population of people and most of the strategies require literacy and very costly. Despite efforts made by Nigeria to adapt and mitigate climate change risk, it is still elementary especially when compared with the disaster caused by climate change.

Therefore this research seeks to investigate the perceptions and actual coping strategies at the farm level adopted by farmers in the study area and make possible suggestions to improve on them. Also, information from this study would be useful to policy makers on climate change. Thus, the research would describe perceptions of farmer households on climate change effect on their crop production, and identify the coping strategies adopted by farm households in the study area.

\section{MATERIALS AND METHODS \\ Description of the Study Area}

The study was carried out in Kano State which is in the North-Western part of Nigeria. The State lies between latitude $12^{0} 37^{\prime}$ North, $9^{\circ} 33^{\prime}$ South and longitude $9^{\circ} 29^{\prime}$ East and 70 43' West. It is bounded by Katsina State to the north-west, and Bauchi and Kaduna State to the south. Kano
State consists of two agro-ecological zones namely, Northern Guinea Savannah and the Sudan Savannah. The southern part of the state is in the Northern Guinea Savannah, which has an annual rainfall of $600-1,200 \mathrm{~mm}$. The central and northern parts are in the Sudan Savannah, with annual rainfall of $300-600 \mathrm{~mm}$ (Kano State Government, 2012).

The State comprises of 44 Local Government Areas, with population of $9,383,682$ people based on 2006 census figure (NPC, 2006). The projected population in 2017 with national growth rate of $3.2 \%$ is $10,160,312$. The predominant ethnic groups are Hausa and Fulani. Agriculture is the major employer of labour in the state with many citizens involved in farming, animal husbandry, and fishery (Kano State Government, 2012).

\section{Sampling Procedure and Sample Size}

A multi-stage sampling procedure was used to select the respondents for this study. In the first stage, the state was divided into two based on agro- ecological zones i.e. Northern Guinea Savannah (NGS) and Sudan Savannah (SS). In the second stage, three Local Government Areas (LGAs) were selected through simple random sampling (names in the hat) from the agroecological zones. Doguwa LGA was selected from Northern Guinea Savannah while Minjibir and Shanono LGAs were selected from Sudan Savannah zone. This selection of only one LGA from NGS was because the Sudan Savannah covers larger area (twice) of land than the Northern Guinea Savannah. The third stage involved simple random selection of three villages from each LGA. They are: Makarfai, Unguwar Rufai, and Falgore Dilmari from Doguwa LGA; Dumawa, Giginyu and Tsakuwa from Minjibir LGA and Kauyen Kuka, Unguwar Gabas and Badumawa from Shanono LGA. The villages had a population of 2,036 farm households based on data collected from Kano Agricultural and Rural Development Authority (KNARDA, 2013). In the final stage $20 \%$ of the sample frame was selected 
randomly to obtain a total sample size of 407 farm households.

\section{Data collection and Analytical Techniques}

Primary data were used for this study. The data were collected by the researcher with the help of trained enumerators. Structured questionnaires were administered to selected household heads (sampling unit) in the study area. Descriptive statistics such as mean, tables, percentages, frequency distribution, and range were used to achieve objectives of the study.

\section{Likert scale}

Likert scale consists of a collection of statements about attitudinal objects. For each statement, respondents have to indicate the degree to which they agree or disagree with its content. This was used to measure the level of agreement of the respondents in order to achieve objective i. The different effects of climate change on their crop production were placed on a 5-point Likert items where 5 = strongly agree, $4=$ agree, $3=$ neutral, $2=$ disagree, and $1=$ strongly disagree.

Perceptions of the respondents on the effects of climate change on their crop production were judged by the mean scores derived from the 5 point Likert items.

\section{RESULTS AND DISCUSSION \\ Farmer Households' Perception of Climate Change}

Farmer's perception of climate change is very important as this enables the farmer to take appropriate measures. The mean scores of respondent's perception were used to discuss the result.

The study showed different opinions of the respondents on climate change. The mean score (M) for decrease in crop production was about 5 and this indicates that the respondents strongly agree that climate change decrease crop production. In addition, increase pest and disease infestation $(M=3.79)$, decrease soil fertility $(M=3.86)$, increase soil erosion $(M=3.84)$, increase in cost of food crops $(M=3.68)$ and decreases food availability $(M=4.25)$ suggest that respondents agreed that climate change has effect on their crop production. While increase in stunted growth $(M=3.25)$ indicated neutral response and it is the least effect perceived by the respondents (Table 1).

The average mean score of the farmer's perception was 3.93. This implies that the respondents in the study area perceived climate change led to decrease crop production. These findings agree with that of Ofuoku (2011), Abraham et al. (2012) and Farauta et al. (2011) that farmers perceived reduction in crop production, increase in pest and disease infestation, decrease food availability, decrease in soil fertility and increase in cost of food crops as common effects of climate change on crop production. Climate change is a serious threat to agriculture and food security especially the rural communities which majorly rely on agriculture to meet their subsistence needs. Shah and Ameta (2008) argued that climate change is directly linked to reduced soil productivity and high incidence of pests and diseases. This is also directly linked to reduced performance of crop production.

\section{Coping Strategies Adopted by Farming Households on Climate Change Effects}

The surveyed farm households adopted a range of coping strategies on the perceived climate change effects (Table 2). The most common coping strategies included changing crop variety which was adopted by nearly $80 \%$ of the respondents, crop rotation (about 41\%), mixed cropping and shifting cultivation constituting about $34 \%$ respectively and changing crop type was adopted by $32 \%$ of the respondents.

Majority $(80 \%)$ of the farmers in the study area plant different crop variety in order to cope with the effects of climate change. This could be attributed to accessibility to different crop variety. This is contrary to the findings of Sofoluwe et al. (2011) where in his study, only $2.8 \%$ of the respondents opted for planting different varieties. This finding is in support of strategies put forward 
by Nigeria National First Communication (2003) and Canada-Nigeria Climate Change Capacity Development Project Reports (2004). These reports emphasized the need for diversification to new plant species and varieties that would have higher resistance to anticipated temperature increase and reduced rainfall. In addition, result of this study indicated that mulching was the least (4\%) coping strategies adopted by farm households. This probably suggests low knowledge about the adaptation measure. This contradicts the study by Idrisa et al. (2012) which shows $80 \%$ of the respondents practicing mulching as an adaptation measure to climate change.

Table 1: Farm household's perceptions of climate change.

\begin{tabular}{|c|c|c|c|c|c|c|c|c|}
\hline Effect on crop production & $\begin{array}{l}\text { SA } \\
(5)\end{array}$ & $\begin{array}{l}A \\
(4)\end{array}$ & $\begin{array}{l}N \\
(3)\end{array}$ & $\begin{array}{l}D \\
(2)\end{array}$ & $\begin{array}{l}\text { SD } \\
\text { (1) }\end{array}$ & $\begin{array}{l}\text { Weighted } \\
\text { score }\end{array}$ & $\begin{array}{l}\text { Mean } \\
\text { Score }\end{array}$ & $\begin{array}{l}\text { Average } \\
\text { mean } \\
\text { score }\end{array}$ \\
\hline 1. Decrease in crop production & 1720 & 224 & 6 & 2 & 4 & 1956 & 4.81 & 3.93 \\
\hline $\begin{array}{l}\text { 2. Increase pest and diseases } \\
\text { infestation. }\end{array}$ & 360 & 996 & 63 & 122 & 4 & 1545 & 3.79 & \\
\hline 3. Decrease soil fertility & 505 & 868 & 66 & 132 & 1 & 1572 & 3.86 & \\
\hline 4. Increase soil erosion & 520 & 844 & 51 & 142 & 4 & 1561 & 3.84 & \\
\hline 5. Increase cost of food crops & 375 & 892 & 69 & 152 & 10 & 1498 & 3.68 & \\
\hline 6. Decrease food availability & 1040 & 496 & 159 & 26 & 9 & 1730 & 4.25 & \\
\hline 7. Increases stunted growth & 355 & 376 & 327 & 260 & 3 & 1321 & 3.25 & \\
\hline
\end{tabular}

$\mathrm{SA}=$ Strongly agree, $\mathrm{A}=$ Agree, $\mathrm{N}=$ Neutral, $\mathrm{D}=$ Disagree, $\mathrm{SD}=$ Strongly disagree

Table 2: Coping strategies adopted by farm households

\begin{tabular}{|c|c|c|}
\hline Coping Strategies & Frequency & $\begin{array}{l}\text { Percentage } \\
(\%)\end{array}$ \\
\hline $\begin{array}{l}\text { 1. Planting different } \\
\text { varieties of crops }\end{array}$ & 324 & 79.6 \\
\hline 2. Change of crop type & 131 & 32.2 \\
\hline $\begin{array}{l}\text { 3. Change to mixed } \\
\text { cropping }\end{array}$ & 133 & 32.7 \\
\hline $\begin{array}{l}\text { 4. Change in planting } \\
\text { dates }\end{array}$ & 37 & 9.1 \\
\hline 5. Crop rotation & 166 & 40.7 \\
\hline 6. Shifting cultivation & 133 & 32.7 \\
\hline $\begin{array}{l}\text { 7. Change from farming } \\
\text { to off- farm activities }\end{array}$ & 28 & 6.9 \\
\hline 8. Water harvesting & 47 & 11.5 \\
\hline 9. Mulching & 17 & 4.2 \\
\hline 10. Planting of trees & 119 & 29.2 \\
\hline $\begin{array}{l}\text { 11. Change to irrigation } \\
\text { farming }\end{array}$ & 21 & 5.2 \\
\hline
\end{tabular}

\section{CONCLUSION}

Farm households in the study area perceived climate change effects on their crop production as majority were of the opinion that it decreases crop production and likewise decreases food availability. The average mean score of farmer's perception was 3.93 meaning that the respondents in the study area agreed that climate change had effects on their crop production.

The study revealed that majority $(80 \%)$ of the farmers in the study area plant different crop variety in order to cope with the effects of climate change. Other coping strategies adopted by farmers included: crop rotation, mixed cropping, shifting cultivation, changing crop type, planting of trees, water harvesting, change in planting date, change to off-farm activities, change to irrigation and mulching.

The use of farm level adaptation measures should be encouraged among farmers. This can be achieved through developing appropriate 


\section{Nigerian Journal of Basic and Applied Science (December, 2017), 25(2): 01-05}

farm-level climate adaptation technologies by research institutes and disseminating them to farmers through extension agents at the appropriate time.

The research shows that most $(80 \%)$ of the respondent used different varieties of crop as their coping strategy to climate change effect in the study area. Therefore, agricultural organizations and research institute should put more effort in developing new varieties of crop that will suit the climatic conditions of the farmers. In addition, farmers should have direct link with the research institutes or seed companies in order to have access to the new seed varieties such as extra early maturing, early maturing and drought tolerant varieties depending on the climatic conditions.

\section{REFERENCE}

Abraham F., Segun, F. B., Adebola, A. J. and Kobe, I. H. (2012). Climate Change Mitigation Activities and Determinants in the Rural Guinea Savannah of Nigeria. Sustainable Agriculture Research, 1(2):172-173.

Building Nigeria Response to Climate Change (BNRCC) (2009). Knowledge is the Key. www.nigeriaclimatechange.org. Accessed on $20^{\text {th }}$ February, 2012.

Canada-Nigeria Climate Change Capacity Development project reports (2004). De Chavez and Tauli-Corpus (eds.) Guide to climate change. www.tebtebba.org . Accessed on $12^{\text {th }}$ March, 2015.

Eboh, E. (2009). Debating Policy Options for National Development: Implication of Climate Change for Economic Growth and Sustainable Development in Nigeria. Enugu Policy Forum Paper 10. African Institute for Applied Economics, pp 13-17.

Farauta, B. K., Egbule, C. L., Idrisa, Y. L. and Agu, V. C. (2011). Farmers' Perceptions of Climate Change and Adaptation Strategies in Northern Nigeria: An Empirical Assessment. African Technology Policy Studies Network. pp1-36.

Idrisa, Y. L., Ogunbameru, B.O., Ibrahim, A.A. and Bawa, D.B. (2012). Analysis of Awareness and Adaptation to Climate Change among Farmers in the Sahel savannah Agro-ecological zone of Borno State, Nigeria. British Journal of Environment and Climate Change, 2(2): 216-226.

IPCC (2007). Impact, Adaptation and Vulnerability. Contribution of Working Group I of the Intergovernmental Panel on Climate Change to Third Assessment Report of IPCC. London: Cambridge university press.

Kano Agricultural and Rural Development Authority (KNARDA, 2013). Farm Families. KNARDA, Kano State, Nigeria.

Kano State Government (2012). Brief on Kano. kano.gov.ng/new/index.php/2012-02-28-03-5105/brief. Accessed on 10th January, 2013.

Maddison, D. (2006). The Perception and Adaptation to Climate Change in Africa. CEEP Discussion Paper No.10, Center of Environmental Economics and Policy in Africa, University of Pretoria, Pretoria.

Nigerian's First National Communication (2003). Under the United Nations frame work Convention on Climate Change (UNFCCC). Ministry of Environment. Abuja, Nigeria.

National Population Commission (NPC), (2006). National population Commission 2006.

Ofuoku, A.U. (2011). Rural Farmer's Perception of Climate Change in Central Agricultural Zone of Delta State, Nigeria. Indonesian Journal of Agricultural Science. 12(2): 63-69.

Ozor, N. (2009). Implications of Climate Change for National Development:- The Way Forward. Enugu policy paper 10, African Institute for Applied Economics.

Shah, R. and N. Ameta ( 2008). Adaptation to climate with a blendof traditional and improved practices. LEISA, 24(4): 9-11.

Sofoluwe, N. A., Tijani,A. A. and Baruwa,O. I.(2011). Farmers' Perception and Adaptation to Climate Changein Osun State, Nigeria. African Journal of Agricultural Research, 6(20): 47894794. 